\title{
As políticas públicas da Igreja Universal do Reino de Deus: o caso de Curitiba
}

\author{
Juliano Eugenio da Silva ${ }^{1}$
}

\begin{abstract}
RESUMO
O texto trata da atuação política da Igreja Universal do Reino de Deus em Curitiba - PR através de seus vereadores eleitos. A partir do trabalho político destes edis intenta averiguar quais as políticas públicas desta igreja para a cidade, ou em outras palavras, quais as políticas públicas produzidas por vereadores iurdianos em âmbito municipal no período de 1997 (a eleição do primeiro vereador da Iurd na cidade) até 2016 (fim da última legislatura). A análise se dá a partir dos documentos legislativos produzidos na Câmara Municipal de Curitiba. Discute questões acerca de patrimonialismo, conservadorismo e fundamentalismo.
\end{abstract}

Palavras-chave: Igreja Universal do Reino de Deus; políticas públicas; drogas; ideologia de gênero.

\section{THE PUBLIC POLICIES OF UNIVERSAL CHURCH OF KING- DOM OF GOD: THE CASE OF CURITIBA.}

\begin{abstract}
The text deals with the political action of the Universal Church of Kingdom of God in the city of Curitiba, through his city councilmen. From the political work of his councilmen try to investigate witch the public policies from this church for the city, or in other words, which were the public policies build by councilmen from the Universal Church to the city in the period of 1997 (the election of the first councilmen of this church) to 2016 (the end of the last legislature). The analysis is based on
\end{abstract}

1 Mestrando em História pela Universidade Estadual de Ponta Grossa - PR (UEPG). Bacharel em Teologia pela Faculdade Batista do Paraná (Fabapar). Bacharelando em Filosofia pela Universidade Federal do Paraná (UFPR). Email: eugeniodasilvajuliano@, gmail.com Currículo Lattes: http://buscatextual.cnpq.br/buscatextual/visualizacv.do?i$\mathrm{d}=\mathrm{K} 8223470 \mathrm{~A} 2$ 
the legislative documents produced at the City Hall of Curitiba. Discuss questions about patrimonialism, conservatism, and fundamentalism.

Keywords: Universal Church of Kingdom of God; public policies; drugs; gender ideology.

\section{Introdução}

A Igreja Universal do Reino de Deus (Iurd) desde pelo menos as discussões parlamentares que culminariam na Constituição Federal de 1988 é parte inconteste da política brasileira. Pastores e bispos desta igreja tem sido eleitos em todos os Estados e em todas as esferas federativas. Desde então o trabalho destes políticos religiosos pôde ser observado no Brasil. Portanto, pode-se perguntar: o que fizeram os representantes políticos desta igreja? Em prol de quê a Iurd trabalhou politicamente no Brasil? Em última instância, que políticas públicas a Iurd produziu através de seus representantes?

Desde que estes atores políticos surgiram, diversos trabalhos foram realizados buscando analisá-los, mormente em âmbito federal; estes trabalhos já trouxeram muita contribuição à academia. Não obstante, a atuação nas esferas estaduais e municipais quedam-se ainda em segundo plano. São deveras poucos os trabalhos que olham para evangélicos em Câmara Municipais, Prefeituras, Assembleias Legislativas e Executivos Estaduais. Na cidade de Curitiba PR estes atores políticos muitas marcas já deixaram desde vereadores com expressivas votações na cidade, até indicados a secretarias municipais, ou discussões em importantes projetos de Lei, como o Plano Municipal de Educação. Tendo em mente esta lacuna em âmbito regional, o objetivo do presente texto volta-se a olhar para estes atores em um ambiente mais localizado e provinciano, a saber, a Câmara Municipal da cidade de Curitiba no período de 1997 (a eleição do primeiro vereador iurdiano na cidade) até 2016 (fim da última legislatura). Como dito, em última instância, o que se intenta é verificar e contribuir para a análise das políticas públicas intentadas pela Igreja Universal do Reino de Deus. 
Religião e poder político são uma problemática constante na vivência humana. Delimitação da atuação de ambos, ingerências, tensões são temáticas sempre presentes e parte da problemática aqui discutida. Analisar a atuação de políticos pertencentes às hostes da Iurd sem dúvida ainda é um assunto de grande relevância para a política pública brasileira. Apesar de esta não ter sido a única igreja a lançar oficialmente candidatos, sua prática política tornou-se de grande sucesso e seu poder político, de grande influência no cenário nacional e municipal. Ademais, em Curitiba, a bancada evangélica obteve grande influência e poder de discussão. Insta, ainda, salientar a $16^{\mathrm{a}}$ Legislatura da Câmara de Curitiba, do período de 2013 a 2016. Durante essa época 11 vereadores de um total de 38 eram evangélicos (CURITIBA, 2013), sendo o presidente da Casa um pastor. Evangélicos estavam em todas as comissões deliberativas. A líder da maioria era evangélica (16 vereadores); a líder da oposição era evangélica; os dissidentes eram liderados por evangélicos (GALINDO, 2015).

A análise histórico-documental norteará a pesquisa, ou seja, a busca pelas respostas às perguntas acima apontadas se dá em olhando-se para os documentos legislativos produzidos pelos vereadores iurdianos em Curitiba; neste sentido, as fontes perscrutadas são os documentos relativos aos processos legislativos pertencentes à Câmara Municipal de Curitiba (CMC), disponibilizados na internet em seu sistema legislativo ${ }^{2}$; ademais, algumas matérias jornalísticas também trazem importantes informações e serão explanadas oportunamente. Ou seja, a partir dos dados constantes nos processos legislativos da $\mathrm{CMC}$, além de matérias jornalísticas, intentar-se-á verificar - quantitativa e qualitativamente - desde de propostas de leis, emendas orçamentárias, audiências públicas, assuntos prioritários nos mandatos, a fim de observar em que medida a Iurd atuou no cenário político municipal.

Diante disso, uma última explanação é necessária: o que entendemos, neste texto, por política pública.

2 Todos os documentos citados como fonte dos processos legislativos estão disponibilizados no site da Câmara Municipal de Curitiba. Disponível em: http://www.cmc.pr.gov.br/wspl/ system/LogonForm.do 
Este conceito de política pública é, em si, objeto de grande discussão. São diversas as correntes interpretativas que tem contribuído para esta temática. Souza (2006) explana algumas das diversas correntes que aportaram definições ao conceito:

Não existe uma única, nem melhor, definição sobre o que seja política pública. Mead (1995) a define como um campo dentro do estudo da política que analisa o governo à luz de grandes questões públicas e Lynn (1980), como um conjunto de ações do governo que irão produzir efeitos específicos. Peters (1986) segue o mesmo veio: política pública é a soma das atividades dos governos, que agem diretamente ou através de delegação, e que influenciam a vida dos cidadãos. Dye (1984) sintetiza a definição de política pública como "o que o governo escolhe fazer ou não fazer”. A definição mais conhecida continua sendo a de Laswell, ou seja, decisões e análises sobre política pública implicam responder às seguintes questões: quem ganha o quê, por quê e que diferença faz. (SOUZA, 2006, p. 24).

Diante de tão grande e complexo campo de estudos, há que se optar por uma definição que melhor se aplique ao objeto estudado. Em nosso caso, em se tratando de uma Câmara Municipal e do trabalho de vereadores, a política pública será entendida como aquela que veio (ou viria) à tona a partir do trabalho destes edis, ou seja, aquilo que o vereador propôs à Cidade por meio de propostas de Lei, ou mesmo através de emendas orçamentárias, programas educacionais, audiências públicas, etc.

\section{A Iurd e a política}

Antes de tratar de práticas parlamentares e em se falando de votos em uma democracia laica, se faz importante o registro acerca das representações formadas em torno da política pública e as práticas realizadas neste campo social. Assim, na intersecção destes domínios a atuação da Iurd deu-se, e a problemática da questão salientou-se; os discursos eleitorais, estratégias de campanha, etc., que Igreja Universal do Reino de Deus empregou. Praticamente estes dois níveis se apresentaram (o das representações e o das práticas). Vejamos ambos. Primeiramente as práticas, 
sendo elas basicamente em dois níveis: a escolha dos candidatos e a estratégia de campanha em si mesma. A Iurd sempre possuiu uma estrutura hierarquizada extremamente forte. Toda a tomada de decisões teológicas, estratégicas, religiosas, empresariais e ainda, as políticas e eleitorais partiam de núcleos específicos de poder (CAMPOS, 1999, p. 379ss), (PROENÇA, 2011, p 199ss). A partir das informações enviadas pelas igrejas locais, o núcleo político traçava suas estratégias, sejam em eleições em âmbito nacional, estadual ou municipal.

[...] na IURD a escolha dos candidatos é prerrogativa única e exclusiva dos dirigentes regionais e nacionais da Igreja, segundo seus próprios cálculos e interesses. Não há nenhuma consulta democrática aos membros das igrejas locais. Estes recebem, no momento oportuno, o(s) nome(s) que devem apoiar (ORO, 2003, p. 56).

O conhecimento do provável nome a ser indicado como candidato da igreja por parte do maior número de pessoas possíveis ajudava em muito na escolha por parte do centro de poder. Neste sentido bispos, pastores, líderes da igreja que fossem "midiáticos" sempre foram privilegiados (como radialistas, p. ex.), afinal se reportariam à igreja.

Por outro lado estava a estratégia de campanha. Por ser igreja, sua estratégia eleitoral sempre esteve relacionada à religião. Aqui as representações do campo político já começam a ser vistas. Se o motivo para se entrar na política é religioso, as estratégias de campanha também o são. É neste sentido que Oro (2003, p. 59) explicita: "a Universal mobiliza na esfera política crenças, valores, símbolos e cosmovisões do seu universo simbólico, e a partir deles produz uma ressemantização do voto, inscrevendo-o "numa lógica cosmológica, na perspectiva da guerra santa"". Mas, de que maneira isto foi feito? Principalmente através da pregação do púlpito. A Universal inseriu a política pública e as relações cidadãs dentro de suas representações de mundo, a saber, do universo de constante luta do bem contra o mal, de um puro maniqueísmo. As palavras de Bispo Carlos Rodrigues, líder supremo da alçada política da Universal durante muitos anos, 
revelam um pequeno prisma de como essas representações da sociedade e da política ocorriam: "O diabo está alojado dentro do Congresso Nacional, criando lei injustas e erradas" (Folha Universal, 302, 18/1/1998, apud ORO, 2003, p. 58). Dessa forma, como toda a teologia da Iurd estava envolta na perspectiva da Guerra Espiritual, sua estratégia de campanha eleitoral, também. A título de ilustração cabe ressaltar a experiência que Ari Pedro Oro, quando das eleições de 2002, presenciou em uma campanha político-religiosa promovida pela Iurd em Porto Alegre:

Esse significado simbólico do voto para os fiéis da IURD ficou bem caracterizado nas eleições de 6 de outubro de 2002. Com efeito, a partir do domingo dia 22 de setembro todos quantos compareceram aos templos da Universal receberam um pequeno envelope que continha um cajado de treze centímetros de comprimento, feito de papelão resistente, portando os dizeres "os 10 dias da libertação". Em verdade, tratava-se de uma "campanha" que iniciou no dia 27 de setembro e que (não por coincidência) terminou no dia 6 de outubro. Como todas as campanhas promovidas pela Igreja, esta também se baseava na Bíblia, mais precisamente em João 8:36, que dizia "Se, pois, o Filho vos libertar, verdadeiramente sereis livres", e em Êxodo 14, que narra a passagem de Moisés pelo Mar Vermelho. Ao explicar essa campanha na "Catedral da Fé", em Porto Alegre, no dia 22 de setembro, o bispo Alfredo Paulo acrescentou: "no dia 6 de outubro nós vamos votar com o cajado". E explicou: "Assim como o Senhor disse a Moisés: levanta a tua vara, estende a mão sobre o mar, e o Mar Vermelho se abriu, assim também nós vamos apertar os números na urna eletrônica com o nosso cajado e vamos abrir o mar do Evangelho, elegendo os homens de Deus. Vamos eleger os homens de Deus que vão trabalhar para a obra de Deus". (ORO, 2003, pp. 59-60).

Dessa forma, demonizar a política sugeria a necessidade de santificá-la, exorcizá-la e para isso ninguém melhor que os pastores lançados pela Igreja. Tendo em vista o âmbito nacional das estratégias de campanha da Iurd, por certo que em Curitiba as campanhas eleitorais deram-se neste mesmo sentido e estilo. Neste contexto deu-se a campanha dos dois vereadores eleitos pela Iurd em Curitiba: exclusivamente na igreja; e, dado o alto número de votos, é de se considerar a aceitação do discurso eleitoral por boa parte dos fiéis. 
Não obstante, existe aqui a tentação de impor aos fiéis da Iurd a pecha de massa de manobra e curral eleitoral. Ou de uma população cega quanto a seus líderes. Tal afirmação corre o risco de relativizar a complexa relação entre pastor e fiel, além de simplificar o problema da recepção desta mensagem por parte do fiel. Convém lembrar as representações que a Iurd mobilizou em torno do mundo: principalmente tomado pelo diabo e carente da salvação divina. A política representou, neste caso, uma esfera emblemática de corrupção carnal e espiritual. Os pastores da Iurd, como enviados de Deus, encarnavam a libertação provinda dos céus (PROENÇA, 2011, p. 201); eram verdadeiros representantes políticos de uma população em busca de soluções para suas mazelas, mas esperançosa com o porvir espiritual. Mais uma vez, se o representante político conseguisse, com seu trabalho, concorrer para o avanço da obra da igreja, muito já teria sido feito. Acrescente-se a isso a constante diminuição dos partidos frente a população enquanto representantes políticos, conforme argumentação de Maia (2012, p. 79ss) e o espaço ocupado, neste sentido, por igrejas por exemplo.

Pressupondo esta baixa institucionalização partidária no Brasil (tal noção será relacionada com a própria ideia de um declínio da importância dos partidos políticos de um modo geral nas democracias ocidentais), serão discutidas as formas alternativas de mediação da relação entre sociedade civil e Estado. Tal mediação, idealmente atribuída aos partidos políticos, não é exercida de modo satisfatório pelos partidos, levando a sociedade a procurar novas formas de organização e reivindicação das suas demandas. Uma das instituições que surgem, então, como pretensas, ou incidentais mediadoras desta relação entre sociedade e Estado é a Igreja. Atuando junto a diversas comunidades e organizando-se enquanto instituição social as Igrejas mobilizam os grupos e, centralizando suas demandas, encontram um contexto favorável para uma atuação como mediadoras da relação sociedade/Estado. Porém, a existência de um contexto favorável à inserção na esfera política, através da mobilização de demandas de diversos grupos sociais, não é suficiente para que determinada instituição (ou segmento) social torne-se, de fato, um ator político considerável. É necessário que, juntamente com uma estrutura social e um contexto favorável, a instituição possua características que viabilizem esta inserção (MAIA, 2012, pp. 79-80). 
E no caso presente, a Iurd verificou um grande campo de atuação, enquanto instituição, no campo político.

\section{Pastor Oliveira - o primeiro eleito.}

Em 1997 a Iurd elegeu seu primeiro vereador em Curitiba. Pastor Oliveira (Bernardino Barreto de Oliveira) foi eleito pelo Partido da Frente Liberal (PFL) com 4.967 votos e iniciou a forte movimentação da Iurd no campo político em Curitiba. A igreja teria uma importante atuação na política municipal a partir de então - não somente com o Pr. Oliveira, que renunciou seu mandato de vereador em 1999 para assumir o cargo de deputado federal, mas também com seu "sucessor" o Pr. Valdemir Soares, eleito a partir da próxima legislatura. Já nesta legislatura, Pr. Oliveira assume a $2^{\circ}$ vice-presidência da Casa.

Nos três anos de seu mandato - antes da renúncia -, este pastor emplacou cinco leis. Uma (9.075/1997) declarou utilidade pública a uma instituição de caridade evangélica; duas (9.301/1998 e 9.296/1998) concederam títulos a cidadãos, respectivamente um magistrado e um pastor; uma (9.295/98) denominou um logradouro público homenageando um pastor; e por fim, a lei 9.280/1998 que "Inclui no calendário do Município de Curitiba o Dia do Evangélico".

Mas o trabalho de um vereador não se reduz à proposição de leis. Praticamente, o que um vereador mais faz é repassar demandas da população ao Poder Executivo. Assim, são centenas de requerimentos à Prefeitura. Porém isso não ocorreu com o primeiro vereador da Iurd em Curitiba. Não houve a proposição de emendas aos orçamentos anuais da cidade, ou seja, este vereador não preocupou-se muito com a destinação das verbas aos problemas da cidade que se achasse conveniente. Do ponto de vista dos requerimentos, não houve nenhum à Prefeitura, ou seja, Pr. Oliveira não teve seu gabinete muito visitado por setores da população exigindo demandas, e se teve, não passou tais demandas à Prefeitura. Apesar destes fatos - sem demandas da população à PMC e sem emendas ao orçamento -, o vereador 
conseguiu eleger-se Deputado Federal com 48.488 votos $^{3}$ nas eleições de 1998. Tal fato mostra que a força da arregimentação eleitoral da Iurd era inegável, a ponto de, por meios próprios, eleger deputados, ou seja, o político da Iurd era um político que não fiava sua atuação frente a população como um todo, mas voltava-se com todas as forças ao eleitorado interno da igreja, mais especificamente durante as campanhas eleitorais e não tanto durante o mandato. Se esse eleitorado estivesse satisfeito, ou ao menos fosse bem convencido da importância da atuação parlamentar de seus pastores, seus votos seriam certos, ou ao menos, suficientemente certos. Dessa forma é possível entender porque a atuação parlamentar para fortalecer a instituição religiosa era tão importante; com mais vigor ainda na Iurd; afinal, se a igreja estivesse crescendo, a possibilidade de votos crescia também e mais cargos políticos podiam ser almejados; desta forma, o contrário também é verdadeiro: se a igreja ia mal - ou não tinha o crescimento esperado - os cargos políticos também diminuíam.

A análise dos políticos da Iurd encontra um excelente representante em Curitiba. Após a eleição de Pr. Oliveira à Câmara Federal e sua renúncia à vereança em 1999, o novo pleito municipal traria a necessidade de um novo candidato, seria ele Valdemir Soares.

\section{O segundo eleito: Pastor Valdemir Soares}

Pastor da Igreja Universal do Reino de Deus, Valdemir Manoel Soares nasceu na cidade do Rio de Janeiro; mudou-se para Curitiba em 1993, onde atuou como pastor e radialista por muitos anos. Nos programas da emissora da igreja pôde estabelecer maior conhecimento de seu nome por parte da população ouvinte e tornando a escolha da instituição ao candidato "pastor midiático".

Em 2000 encarou seu primeiro pleito eleitoral. Já neste certame foi eleito pelo Partido Progressista Brasileiro (PPB) com

\footnotetext{
Dados disponíveis no site do Tribunal Superior Eleitoral (TSE). Disponível em http:/ www.tse.jus.br/eleicoes/eleicoes-anteriores/eleicoes-1998/resultado-da-eleicao-de-1998 acesso em 01/08/2016.
} 
10.691 votos, a nona melhor votação da cidade (REIHBEIN, 2008, p. 312); Pr Oliveira havia sido eleito quatro anos antes com 4.967 votos, ou seja, a Iurd conseguiu mais que dobrar o número de votos de seu candidato em apenas uma legislatura e dessa forma foi consolidando sua forte presença na Câmara de Curitiba.

A partir de então Pr. Valdemir Soares iniciou sua importante atuação no parlamento municipal, onde conseguiu sucessivas reeleições - sempre entre as melhores votações da cidade - até sua renúncia em 2016, quando foi flagrado por câmeras votando por outra vereadora em uma sessão da Câmara, ou seja, fraudando a votação em plenário. Antes que seu processo de cassação fosse aberto, apresentou sua renúncia. Pouco depois a igreja o transferiu para Manaus para ali continuar seu pastorado.

Passemos pois a atuação e prática política deste pastor. Em seu primeiro mandato, Pr. Valdemir Soares apresentou 19 projetos de lei. Dos 19, oito foram aprovados e sancionados; 10 foram arquivados no trâmite processual; e um foi vetado pelo prefeito. Destes 19, 8 tem relação direta com a religião. Alguns que chamam a atenção são: projeto de Lei que "Dispõe sobre a isenção de pagamento do Imposto sobre a Propriedade Territorial e Urbana - IPTU, às entidades que menciona [templos religiosos] e dá outras providências", que em sua justificativa explana:

Ao Município é vedado instituir impostos sobre os templos religiosos, estando incluído nesta proibição o lançamento do Imposto Predial e Territorial Urbano - IPTU, sobre as referidas entidades. Entretanto, muitos dos templos religiosos existentes em nossa Capital utilizam-se de imóveis locados por terceiros, o que faz com que a municipalidade venha a lançar o referido imposto sobre ditos bens, uma vez que os imóveis não são de propriedade das referidas entidades religiosas. Para que se possa corrigir esta distorção, é que se apresenta o presente projeto de lei complementar. (SOARES, 2002).

Tal proposição tramitou até 2009 quando foi arquivada.

Outro projeto de lei emblemático foi o que "Dispensa a exigência de Alvará de Funcionamento para Templos Religiosos”, porém, após anos de tramitação, foi arquivado em 2009 pela comissão de Legislação e Justiça - que o analisou uma segunda vez 
- principalmente pela ocorrência de acidentes envolvendo templos religiosos, o que levantou a preocupação dos vereadores. Vale a leitura do parecer $n^{\circ} 541 / 2009$ da referida comissão:

Com certeza o parecer anterior desta Comissão, foi muito superficial e deixou de analisar o aspecto constitucional da norma que se pretende aprovar, ao ser favorável a tramitação do projeto. Da mesma forma, também a instrução do Projuris [setor jurídico permanente da CMC] preocupou-se apenas com a existência de Projeto semelhante. Contudo, acontecimentos envolvendo desabamento e incêndios de templos religiosos, no Brasil e no mundo, são um alerta para a necessidade de fiscalização sobre estes locais que reúnem, centenas ou milhares de pessoas. Importante ressaltar, que conforme informação da Vereadora Professora Josete [PT], contida no parecer da Comissão de Serviço Público, Lei semelhante no Distrito Federal foi objeto de Ação Direta de Inconstitucionalidade, já que impedia o exercício do poder (dever) de polícia da administração pública (CURITIBA, 2009).

Outro projeto importante foi o que "Dispõe sobre a instituição da Marcha para Jesus" transformado em Lei posteriormente (Lei ordinária 11.361/2005). Sobre esse tema um fato curioso ocorreu, vejamos. Quando justificou seu projeto, Pr. Valdemir Soares, explanou:

A Marcha para Jesus realiza-se em diversas Capitais do Brasil, sempre com o objetivo de louvar ao nome de nosso Deus, atingindo a todas as igrejas, sejam evangélicas ou não. Para que Curitiba também integre esse rol de Capitais brasileiras que louvam a Deus com uma marcha em um determinado dia por ano, é que apresentamos o presente projeto para que seja discutido e aprovado pelos nobres pares desta Casa de Leis (grifo nosso) (SOARES, 2002b).

Ocorre que uma emenda foi apensada a esse projeto por um vereador católico, solicitando a seguinte imposição à letra do texto legal:

O evento será ecumênico e, obrigatoriamente, contará na sua organização com a participação efetiva da Igreja Católica, através da Arquidiocese de Curitiba; [...] Fará parte da Marcha para Jesus, em toda sua trajetória, a imagem de sua mãe Nossa Senhora da Luz, padroeira de Curitiba." [e justifica]: "[...] haja vista que a grande maioria de nossos munícipes são 
católicos, nada mais justo prestarmos esta homenagem, concomitantemente a Padroeira de Curitiba: Nossa Senhora da Luz, Mãe de Jesus, transportando sua santa imagem nesta bonita Marcha pelas ruas de Curitiba, que com certeza causará uma corrente muito de forte de devoção e oração num dia singular, para todos os religiosos de nossa Capital Social (STEPHANES JR., 2004).

Quando Pr. Valdemir Soares colocou na justificativa de seu projeto que a Marcha para Jesus seria de alguma maneira ecumênica, afinal atingiria "todas as igrejas, evangélicas ou não", sua intenção parece ser a de querer convencer seus pares da necessidade e da importância de tal Marcha, que ocorria no mundo todo. Mas tal afirmativa não foi verdadeira. A Marcha para Jesus que se instalou no Brasil não foi um movimento ecumênico; a marcha era total e eminentemente evangélica. E como sabido, uma das características do protestantismo brasileiro era a distinção e a diferença identitária de sua religiosidade com o catolicismo (SOUZA, 2012). Para o evangélico brasileiro pentecostal e neopentecostal um dos maiores pecados de um católico era a idolatria, representada pelas imagens e esculturas presentes na religiosidade católica. Fato marcante ocorrido e que ilustra cabalmente este repúdio foi o episódio do "chute na santa", quando em programa de televisão no ano de 1995, o então Bispo da Iurd Sérgio Von Helde, proferiu insultos e chutou uma imagem de Nossa Senhora Aparecida. Apesar de este evento ter sido isolado não representando o todo evangélico, é uma mostra da grande dificuldade entre evangélicos e as imagens católicas. Dessa forma, seria inadmissível que uma imagem fosse conduzida em um evento evangélico desse porte.

Por certo que tal emenda à lei não prosperaria por desvirtuar toda a sistemática e essência da Marcha para Jesus, e não prosperou. Quando o projeto foi aprovado, em 2005, em dois turnos pelo plenário da $\mathrm{CMC}$, a assessoria de imprensa da casa publicou em seu sítio eletrônico uma matéria acerca do projeto.

O movimento evangélico "Marcha para Jesus", simultaneamente realizado em mais de cem países e, nacionalmente, nas principais cidades do Brasil, fará parte do calendário de eventos de Curitiba. Projeto de lei de iniciativa do vereador licenciado Pastor Valdemir Soares (PL) foi aprovado durante 
sessão plenária da Câmara Municipal, na tarde desta terça-feira (15), em segundo turno. Debatido e votado em primeiro turno na tarde de segunda-feira (14), o projeto gerou polêmica pela inclusão de uma emenda do vereador Reinhold Stephanes Júnior (PMDB), que acabou sendo retirada pelo autor, após extensa discussão, entre correntes de vereadores evangélicos e católicos. O bom senso democrático prevaleceu na liberação da matéria de cunho essencialmente evangélico, e não ecumênico, como pretendido na emenda de Stephanes Júnior (CURITIBA, 2005).

Apesar desta atuação eminentemente religiosa, outra área de atuação deste parlamentar que caracterizou fortemente seu trabalho foi a relacionada ao combate irrestrito às drogas ilícitas ou lícitas. Através deste campo de atuação Pr. Valdemir Soares realizou inúmeros e grandiosos eventos na cidade. Concatenando a estrutura e apoio do Município com a grande estrutura da Iurd, seus eventos congregaram milhares de pessoas em Curitiba.

Ocorre que o pastor, mesmo enquanto vereador, esteve trabalhando na igreja em programações para os jovens e adolescentes. A grande estratégia de Valdemir Soares neste campo foi o de conseguir congregar em um único evento a atuação religiosa e sua atuação social como vereador. Sua igreja realizou inúmeros eventos religiosos - com cantores gospel nacionais e internacionais; celebridades evangélicas; e etc. - com cunho antidrogas. Assim Valdemir Soares conseguiu trazer o apoio do município a estes eventos. Frise-se: a igreja realizava os eventos e era apoiada pela prefeitura. Nestes eventos gigantescos - em casas de shows, parques, praças, ruas da cidade, etc. - a Iurd apresentava seus pastores, realizava cultos, fazia apelos de conversão, pedia contribuições financeiras, etc. Enfim, a Iurd conseguiu grandes contribuições públicas através do trabalho deste vereador. E o prefeito? De 2001 a 2012 Valdemir Soares foi da base aliada, sendo inclusive Secretário Municipal de Habitação em 2008.

Projetos sociais antidrogas reuniram-se, no último sábado [21/04/2012], para promover um evento contra o crack. A atividade "Cortando o Crack", organizada pela Força Jovem Paraná, da Igreja Universal do Reino de Deus, mobilizou cinco mil jovens neste final de semana, [...] O parlamentar [Pr. Valdemir] tem sistematicamente trazido este debate para a Câmara de Curitiba, relatando em plenário os sucessos obtidos pelo 
movimento social e realizando seminários que debatem os malefícios do uso de substâncias ilícitas pela juventude. Em 2011, por exemplo, o vereador realizou uma audiência pública em que jovens [todos da Iurd] manifestaram-se contra a legalização da maconha. Durante o evento, Valdemir Soares destacou o pioneirismo da prefeitura nas políticas públicas do setor, por ter criado a primeira Secretaria Municipal Antidrogas do Brasil. "Nós estamos juntos nessa luta e temos muito a fazer pela juventude curitibana. As ações do município tornam esse trabalho mais eficaz", destacou o vereador. [O prefeito] Luciano Ducci explicou aos jovens como funcionam os programas de combate às drogas em Curitiba, desenvolvidos em parceria com a sociedade civil e elogiou a participação dos jovens na atividade. "Tenho muito carinho e admiração pelo trabalho da Força Jovem na luta contra as drogas", disse o prefeito. O evento desse final de semana foi o terceiro encontro esportivo realizado pela Força Jovem. As edições anteriores prestigiaram as artes marciais (Nocaute no Crack) e o jogo de basquete (Enterrando o Crack). Os organizadores integram o movimento "Curitiba, te quero sem drogas", criado em 1992 para promover atividades de sensibilização da população para o problema dos entorpecentes (CURITIBA, 2012).

O grande esforço deste vereador em prol dessas bandeiras se deu também em nível de legislador. Neste sentido, já em 2001, houve um projeto de Lei - posteriormente lei ordinária $11.325 / 2004$ - que "Estabelece a obrigatoriedade dos estabelecimentos de ensino localizados no Município, afixarem em local visível, com destaque, os malefícios do fumo, bebidas alcoólicas e drogas" (SOARES, 2001); em seu artigo $1^{\circ}$ a lei explana:

Todos os estabelecimentos de ensino localizados no Município ficam obrigados a afixar [...] a seguinte expressão: O FUMO, A BEBIDA ALCOÓLICA SÃO TERRIVELMENTE PREJUDICIAIS À SAÚDE; A DROGA MATA[grifo original] (SOARES, 2001).

Em seu último mandato (2013-2016) criou a "Frente Parlamentar contra o crack e outras drogas". Por sua iniciativa a Câmara de Curitiba realizou a "audiência pública contra a legalização da maconha”, quando diversas autoridades públicas, da sociedade civil, e jovens (da igreja) posicionaram-se contra a legalização da maconha. Veja-se que a Audiência não foi sobre a possibilidade de se legalizar a maconha, ou discutir o assunto, 
mas sim acerca da necessidade de se posicionar contra a legalização (CURITIBA, 2011).

Do ponto de vista dos requerimentos a órgãos públicos ou não, Pr. Valdemir Soares usou seu primeiro ano de mandato, 2001, quase que exclusivamente em prol da Iurd. Foram três requerimentos à Prefeitura, dois deles relacionados ao templo central da Iurd em Curitiba e seus entornos. O primeiro pedia alteração do nome da estação tubo (local de parada de ônibus expresso em Curitiba) Alferes Poli para "Catedral da fé", ou seja, em frente a Iurd existia uma parada de ônibus com o nome de Alferes Poli, a solicitação é para que tal parada tenha seu nome relacionado ao templo religioso, facilitando a identificação aos passageiros que para lá se dirigiam; tal requerimento foi atendido e desde então a estação tubo em frente ao grandioso templo chama-se "Catedral da Fé”. O segundo requerimento,

Requer a construção de 'trincheiras' nas Ruas Desembargador Westphalen e Alferes Poli, ambas esquinas com Av. Sete de Setembro, bem como a implantação de asfalto definitivo na Rua Alferes Poli (SOARES, 2001b).

\section{A justificativa para tal requerimento:}

Por si o fluxo do trânsito no local é intenso, principalmente nos horários de "pico", existindo no local um grande templo religioso [templo central da Iurd] que recebe fiéis todos os dias em diversos horários, aumentando ainda mais a quantidade de veículos que transitam pelas referidas ruas. A implantação das "trincheiras" virá desafogar o trânsito, evitando diversos transtornos que existem atualmente (SOARES, 2001b).

Porém esta requisição não foi atendida por não ser viável no que diz respeito à engenharia do trânsito.

Em 2002, Valdemir Soares alargou um pouco mais seus requerimentos à PMC e se tornou mais um Vereador clássico - mas não deixou de lado suas solicitações "iurdianas": das quatro solicitações à Prefeitura, uma é para limpeza de terreno, duas para instalação de sinaleiros, e uma solicitação para alteração em um ponto de ônibus que estava muito perto da entrada do estacionamento do templo central da Iurd e oferecia "risco aos veícu- 
los", conforme justificativa da demanda. A outros órgãos foram dois requerimentos neste ano: um ao Departamento de Trânsito que solicitava substituição de todos os radares de Curitiba para Lombadas eletrônicas; e um à Telepar (Companhia Paranaense de Telecomunicações) solicitando a instalação de um telefone público em frente a Rádio Record.

Em 2003 e 2004 foram dois requerimentos à PMC: "Requer parada de ônibus biarticulado" na Catedral da Fé"; e "Requer informações sobre o 'show' de Roberto Carlos, no Município de Curitiba”. Tais requerimentos não foram atendidos.

No que diz respeito às emendas ao orçamento municipal Pr. Valdemir Soares ficou os dois primeiros anos silente, ou seja, não requereu acréscimos ou supressões ao orçamento municipal. Em 2003 foram duas emendas aprovadas ao orçamento do ano posterior, ambas relacionadas a instalação de anti pó (uma espécie de asfalto mais fino). Em 2004 Pr. Valdemir Soares teve cinco emendas aprovadas ao orçamento municipal do ano posterior, todas elas relacionadas ao trânsito da cidade, como instalação de anti pó ou de semáforos.

Neste primeiro mandato do Pr. Valdemir Soares, é possível notar algumas características da atuação parlamentar de um vereador da Iurd; tais características permaneceram presentes em todos ou outros mandatos do vereador, sendo qualitativamente redundante tratar de todos individualmente; o que mais mudaria seria o número de solicitações à $\mathrm{PMC}$, mas sempre relacionadas à Iurd.

O fato é que em todos os seus mandatos o vereador esteve na Câmara Municipal a serviço de sua igreja. O trabalho destacou-se no âmbito religioso e no combate às drogas, ou seja, questões morais. Não obstante, houve solicitações mais clássicas, como relacionadas a trânsito, limpeza, e etc. Vale a lembrança de Leonildo Campos:

Neste contexto, adquiriu corpo a ideia que há um novo político evangélico, que está enraizado nos objetivos de sua própria denominação religiosa ou seita, o qual nunca esconde que sua função nas casas legislativas ou 
nos aparatos do Estado, é a de defender os interesses corporativos e institucionais. (CAMPOS, 2005, p. 161, tradução nossa) ${ }^{4}$.

Ao menos duas conclusões podem ser tiradas desta atuação parlamentar: a primeira é a de que os vereadores evangélicos são muito parecidos como seus pares, por atuarem em campos específicos, sendo a área religiosa mais um campo a se explorar em trabalho; a segunda é a de que a atuação relacionada à religião, foi motivo de grande preocupação, inclusive quanto a qualidade da luta e esforços empenhados. Era nesse campo que as opiniões eram mais extremadas e intransigíveis. Em outros campos se atuava como parlamentar, neste campo se atuava como missionário. Esse aspecto ficará mais claro quando tratarmos de sua atuação no Plano Municipal de Educação, mas por agora, já se vislumbram estes caracteres.

Outro quesito importante foi a atuação relacionada às questões da Igreja Universal de Curitiba e suas demandas; ou seja, houve o trabalho em prol, não necessariamente de eleitores, mas sim de sua igreja. Essa distinção é muito importante, principalmente pela volatilidade dos frequentadores da Iurd. Por exemplo essa igreja não possuía um rol de membros inscritos ou de frequentadores, mas somente um registro daqueles batizados. $\mathrm{E}$ essa atuação institucional nos leva a um problema, a questão da missão e do patrimonialismo. De uma maneira simples, este conceito pode ser traduzido na "utilização da coisa pública, como se privada fosse" ou ainda, a utilização de meios públicos para fins privados. Mas esse quesito seria atenuado com a representação de que se estes fins privados fossem o "pregar o Evangelho", valeria a pena usar a coisa pública.

4 En ese contexto, adquirió cuerpo la idea de que hay un nuevo político evangélico, que está enraizado en los objetivos de su propia denominación religiosa o secta, lo cual nunca esconde que su función en las casas legislativas o en los aparatos de Estado, es la de defender los intereses corporativos e institucionales. 


\section{Atuação missionária - Plano Municipal de Educação}

No ano de 2015 o Plano Municipal de Educação (PME) foi discutido na Câmara de Curitiba. Esta importante legislação moldaria a educação na cidade pelo período de dez anos. Fruto de uma extensa discussão dos setores educacionais da cidade, o projeto de Lei continha vinte e cinco metas e mais de trezentas estratégias para a educação no Município. Mas quando chegou à Câmara, o assunto foi um só: a "ideologia de gênero". Valdemir Soares participou ativamente da discussão na Câmara; foi um dos mais ferrenhos combatentes conservadores. Suas palavras e ações nesta discussão revelam aspectos primordiais da luta de religiosos em questões relacionadas à moral e costumes, mormente as temáticas dos gêneros e homoafetividade.

Quando o projeto de lei passou pela Comissão de Constituição e Justiça, Valdemir Soares, enquanto participante da comissão, emitiu seu voto em separado. "Nestes dispositivos [do PME enviado à Câmara Municipal] constam previsões sobre a ideologia de gênero, que foram retiradas do texto final do Plano Nacional de Educação" (SOARES, 2015).

Mas o que seria esta ideologia de gênero? O vereador nos explica. Usando como fonte de informações dois sites da internet, um sendo da plataforma "wiki" - domínios de preenchimento voluntário, livres de maiores rigores científicos, passíveis de graves erros teóricos e/ou metodológicos - e um reconhecido site conservador chamado "Biopolítica". As definições presentes no voto, retiradas de tais domínios, são importantes na medida em que revelam as representações que alguns setores evangélicos formaram em torno da "ideologia de gênero". Ei-los:

Para maior entendimento do que é a ideologia de gênero, trazemos o conceito do mesmo, segundo o site Sofos, que pode ser conferido no seguinte endereço eletrônico: http://sofos.wikidot.com/ideologia-de-genero. "A Ideologia de Gênero, ou melhor dizendo, a Ideologia da Ausência de Sexo, é uma crença segundo a qual os dois sexos - masculino e feminino - são considerados construções culturais e sociais, e que por isso os chamados 'papéis de gênero' (que incluem a maternidade, na mulher), que decorrem das diferenças de sexos alegadamente 'construídas' - e que 
por isso, não existem -, são também "construções sociais e culturais"”. Segundo o site Biopolítica, a ideologia de gênero afirma que o homem e a mulher não se diferem pelo sexo, sendo imposto pela sociedade, vejamos: "A ideologia de gênero afirma que o homem e a mulher não diferem pelo sexo, mas pelo gênero, e que este não possui base biológica, sendo apenas uma construção socialmente imposta ao ser humano, através da família, da educação e da sociedade. Afirma ainda que o gênero, em vez de ser imposto, deveria ser livremente escolhido e facilmente modificado pelo próprio ser humano. Ou seja, que ao contrário do que costumamos pensar, as pessoas não nascem homens ou mulheres, mas são elas próprias condicionadas a identificarem-se como homens, como mulheres, ou como um ou mais dos diversos gêneros que podem ser criados pelo indivíduo ou pela sociedade. Deveria ser considerado normal passar de um gênero a outro e o ser humano deveria ser educado, portanto, para ser capaz de fazê-lo com facilidade, libertando-se da prisão em que o antiquado conceito de sexo o havia colocado. Para facilitar o ativismo em favor do gênero, a Conferência de Yogiakarta, realizada em 2006 na Indonésia, consagrou os termos 'identidade de gênero' e 'orientação sexual' (http:// biopolitica.com.br/index.php/news/39-insercao-da-ideologia-de-genero-em-todos-os-municipios-do-brasil)" (SOARES, 2015).

Muitas coisas poderiam ser discutidas das afirmações acima constantes como justificativa. Mas algumas questões urgem. Primeiramente, cabe destacar que o vereador ancora seu voto constante da discussão de uma lei que impactará os próximos dez anos da educação da cidade, em dois textos retirados da internet. $\mathrm{O}$ fato de provirem da rede internacional de computadores não desqualifica o conteúdo em si. O que os torna altamente questionáveis é o fato de que não dialogam com nenhuma área acadêmica ou científica. Atacam aquilo que chamam de "ideologia" mas não nomeiam seus adversários. Note-se que os dois textos citados fazem fortes afirmações atentando para algo que desnaturalizaria as relações e papéis humanos, mas não dizem qual seria uma possível resposta a isso. Em consulta a tais páginas na internet, constatou-se que os textos foram citados em sua inteireza; não há bibliografia ou indicação da área de estudos dos autores. Não há aqui uma preocupação seletiva com a informação e sua fonte, e nem ao menos uma discussão sobre a proveniência e qualificação das informações apresentadas pelo edil em seu argumento. 
Ocorre que essas questões levantadas no voto não são meramente questões jurídicas ou sociais, mas são questões de fé. Se algo tenta contrariar a criação e o ordenamento divino, neste caso, de ótica cristã, aí está o problema e a conspiração. E se a família é o ordenamento divino por excelência no que diz respeito à vida social, algo que contra ela supostamente aponte-se é digno de execração, mesmo a escola.

As escolas devem transmitir conhecimento e instrução, relacionadas às matérias curriculares como português, matemática, ciências, etc, cabendo aos pais a educação dos filhos propriamente dita, inclusive sobre questões mais delicadas como sexo e drogas. [...] Além disso, o PME deve seguir o regramento constitucional, a fim de assegurar a manutenção e o desenvolvimento da educação, sendo que cabe às escolas transmitir ensinamentos aos estudantes, em sentido estrito, já que deve seguir as diretrizes da Lei de Diretrizes e Bases da Educação, cabendo à família educar os filhos, em sentido amplo, aí compreendendo a ideologia de gênero e orientações sexuais, não podendo o Estado se imiscuir nesta seara (SOARES, 2015).

Mas, mais uma vez, apesar destas questões jurídicas e técnicas - p. ex. termos que não apareciam no Plano Nacional constarem no Plano Municipal - o ponto que nos parece crucial neste debate é a ideia de que devem existir limites para a ação do Estado na educação das crianças e jovens. O limite é a família e seus valores, pois caberia aos pais a educação dos filhos em sentido amplo sobre questões mais delicadas como sexo, ideologia de gênero e drogas. Portanto, ao introduzir termos como gênero e diversidade no PME, a Prefeitura Municipal, na argumentação do edil, além de infringir a legalidade constitucional, estaria se imiscuindo numa "seara" que não lhe competia: a educação das crianças e jovens em "sentido amplo".

No trecho acima uma nota é essencial: Valdemir Soares sempre legislou tenazmente contra todo e qualquer tipo de drogas. Como já visto neste texto, uma lei de sua autoria obrigava a fixar-se cartazes contra drogas em escolas municipais; embora diga acima que as drogas são assunto para a família, não foi essa sua 
prática; mas com relação a discussão de gênero sua perspectiva se altera: trata-se de assunto privativo para ser discutido pela família.

Quando o projeto foi a plenário, Valdemir Soares manteve-se irredutível. Foi um dos mais ativos durante a sessão. Suas palavras denotam um tom de nervosismo e mesmo irritação. Foi, sem dúvida, o vereador mais exaltado; discursou e fez uso da palavra diversas vezes. Iniciou chamando a atenção para o que considerou como a inconstitucionalidade do PME ao chegar à CMC com as palavras "gênero" e "diversidade" que, para ele, indicavam incontestavelmente a "ideologia de gênero" e destruição da "família natural".

Foi aprovado um plano nacional de educação, discutido exaustivamente no Congresso Nacional, onde se foi retirado toda a qualquer questão de identidade e de gênero, diversidade ou orientação sexual, e aqui na Cidade de Curitiba aparecem com um novo plano totalmente fora dos padrões constitucionais da legalidade do que foi aprovado no Congresso Federal. Eu pergunto aos Srs. Vereadores: nós somos idiotas? Nós somos burros? (CURITIBA, 2015).

Seguindo sua fala, este vereador desqualificou a discussão prévia do PME feita pelo Fórum e Conferência Municipal de Educação.

E o Vereador Salamuni disse que foi exaustivamente discutido pela comunidade. Vários seguimentos não participaram, não foram chamados, porque se fossem chamados o plano não vinha do jeito que veio. E se fossem chamados, contemplados, não havia necessidade da comunidade estar presente aqui. Houve sim uma atuação não técnica, não constitucional, mas uma atuação política, segmentada, segregada para que o plano chegasse aqui de alto a baixo com apologia, identidade de gênero e orientação sexual (CURITIBA, 2015).

As palavras acima já demonstram fortes características de fundamentalismo, seja pela desqualificação do debate e da negação do discurso opositor, seja pela pretensa "denúncia" de uma conspiração de determinados setores políticos com fins malévolos. Mas as palavras abaixo demonstram a qualidade do discurso do 
parlamentar, ou melhor, a maneira como a discussão em torno da questão dos gêneros foi vista.

A maioria das nossas crianças que estudam nas nossas escolas municipais é de zero a doze anos. Criança de zero a doze anos vai para a escola para aprender a ler e a escrever, vai para aprender matemática, geografia, história, português. Ela não vai para aprender identidade de gênero, ela não vai para aprender a fazer sexo, variações de sexo, com pessoas do mesmo sexo dela. Não, de forma alguma. Isso é um absurdo. É chamar este parlamento de idiota. Entregar o plano como foi entregue aqui é chamar o parlamento de idiota. Vocês acham que vamos nos dobrar? [...] A questão de gênero, orientação sexual, diversidade é algo que cresceu nesses vinte e dois dias no parlamento, com a maioria dos parlamentares, porque não precisa ter bandeira, religião para entender que o que tem que ser aprendido na escola é diferente do que tem que ser aprendido dentro de casa. Orientação sexual para criança, para adolescente, é da mãe para a filha no momento ideal, é do pai para o filho no momento ideal. Professor que é professor não tem que se meter nisso não. Professor tem que ensinar português, matemática, geografia, história, ensinar a ler e escrever. Professor tem que ensinar isso. Então, por favor, a todos que estão por trás dessa fabricação deste plano municipal, não somos idiotas, o parlamento não é idiota, a sociedade está aqui presente porque a sociedade não é idiota. [...] É uma vergonha para a Cidade de Curitiba uma Casa que trabalha, que promete pela Constituição Nacional, pela constitucionalidade e pela obediência à Lei Orgânica, receber um Plano Municipal vilipendiado, mascarado, um plano extremamente voltado para outra situação que não é a educação. Não vi aqui nenhum outro problema no plano, nenhuma questão técnica além dessas questões. Por que será? Quem é que está por traz [sic] disso? Qual o interesse disso? (CURITIBA, 2015).

Nas palavras do pastor - e na visão fundamentalista - toda a discussão de gênero resume-se à sexualidade. Discutir as temáticas dos gêneros, para ele seria ensinar a "fazer sexo, variações de sexo, com pessoas de mesmo sexo dela". O problema também está na repulsa à homoafetividade. $\mathrm{O}$ que estaria em jogo, em última instância, seria a heteronormatividade. Em sua fala, vê-se a cólera contra um inimigo real (ou imaginado) que estaria a destruir fundamentos de sua fé e moralidade. Uma conspiração de agentes para influenciar as crianças em suas sexualidades. Toda uma problemática de violência de gênero, de preconceito, enraizados 
na sociedade, de luta por melhores condições sociais por sujeitos historicamente discriminados foram relegados a questões sexuais e comportamentais. Enfim, todo esse discurso deu-se nestes termos de indignação, de luta contra os termos gênero e diversidade, de orquestração para destruir a família, e etc.

Assim, através da atuação deste pastor da Iurd - em conjunto com a bancada evangélica e alguns segmentos católicos - os termos "gênero" e "diversidade" foram totalmente retirados do Texto final do PME. Nestes quesitos não houve possibilidade de recuo. Através da fé, aliada a alguns quesitos jurídicos, o texto da Lei foi alterado.

A atuação deste vereador na CMC acabou de maneira trágica. Na sessão plenária de 31 de março de 2016, durante uma votação no plenário, Valdemir Soares foi flagrado por câmeras supostamente votando em lugar de outra vereadora, ou seja, fraudando a votação. As imagens e a grande evidência dada ao fato pela mídia local geraram um enorme mal estar na Câmara de Curitiba, até que veio a carta de renúncia. A assessoria de imprensa da Casa assim relatou o ocorrido.

Acusado de ter fraudado uma votação na Câmara Municipal de Curitiba, e após ter sido denunciado à Mesa Diretora pela vereadora Julieta Reis (DEM), o vereador Valdemir Soares (PRB) renunciou ao mandato durante a sessão desta quarta-feira (6[04/2016]). Em um discurso de 30 minutos, Soares, que estava no $4^{\circ}$ mandato, voltou a negar que tivesse votado no lugar da colega, disse ter a consciência limpa e que a ação contra ele foi fabricada. Ele também pôs em dúvida o sistema de votações da Casa e falou sobre suas ações em benefício da população no período em que foi vereador. Após sua fala, não houve contestação por parte da Mesa Diretora ou outros parlamentares porque encerrou o tempo regimental da sessão. "Saio pela porta da frente e vou continuar a fazer o trabalho social que sempre fiz. Sei que se eu me defendesse dessa acusação eu seria inocentado, mas por respeito a Curitiba decidi renunciar. Tenho a consciência limpa de que não votei pela vereadora e nunca tive nenhuma conduta que ferisse a ética e o decoro parlamentar. Mas, da forma como os fatos foram noticiados, não pareceu honesto da minha parte permanecer. E tão importante quanto ser honesto é parecer ser honesto", disse (CURITIBA, 2016). 


\section{Considerações Finais}

A Iurd é parte da política pública nacional incontestavelmente. Há muitos anos vem trabalhando nas esferas públicas de poder. A constatação da academia acerca destes atores desde muito concluiu que muito trabalho foi empenhado em proveito próprio (FRESTON, 1993), (CAMPOS, 1999), (BAPTISTA, 2007), (MAIA, 2012). Nada muito distinto ocorreu nas esferas municipais, ao menos na curitibana. Seus dois pastores eleitos à vereança em muito trabalharam em prol de sua igreja. O fato é que em todos os seus mandatos os vereadores estiveram na Câmara Municipal a serviço de sua igreja. $\mathrm{O}$ trabalho destacou-se no âmbito religioso e no combate às drogas, ou seja, questões morais. Não obstante, houve trabalhos mais clássicos, como relacionadas a trânsito, limpeza, e etc.

Diante disso viu-se que os vereadores iurdianos são muito parecidos como seus pares, por atuarem em campos específicos, sendo a área religiosa mais um campo a se explorar em trabalho; há também que se ter em mente que a atuação relacionada à religião: foi motivo de grande preocupação, inclusive quanto a qualidade da luta e esforços empenhados. Era nesse campo que as opiniões eram mais extremadas e intransigíveis. Em outros campos se atuava como parlamentar, neste campo se atuava como missionário.

Neste quesito de atuação missionária, a discussão parlamentar na CMC do Plano Municipal de Educação tornou-se em exemplo ímpar de caracterização. Tendo um inimigo, não um adversário, (real ou imaginado) bem definido, no caso, a chamada ideologia de gênero, lutou-se tenazmente contra os termos gênero e diversidade. Vê-se a cólera contra um inimigo que estaria a destruir fundamentos de sua fé e moralidade. Uma conspiração de agentes para influenciar as crianças em suas sexualidades. Toda uma problemática de violência de gênero, de preconceito, enraizados na sociedade, de luta por melhores condições sociais por sujeitos historicamente discriminados foram relegados a questões sexuais e comportamentais. 
É neste complexo campo que a Iurd conseguiu concatenar oferta de trabalhos religiosos com atuação pública, com vista a um fim: o crescimento próprio. Alie-se a isso, a atuação conservadora nas questões morais e comportamentais.

Assim, em Curitiba, dois polos podem ser observados através da atuação dos vereadores iurdianos: o trabalho que se volta para interesses próprios - seja na alocação de esforços em torno dos interesses corporativos - seja na luta para assuntos relacionados a sociedade como um todo. Neste quesito, as políticas públicas intentadas pela Iurd podem ser tidas como conservadoras, seja na luta renhida contra as drogas e a discussão por legalização, seja nos assuntos relacionados à diversidade sexual e a questão dos gêneros.

\section{Referências}

BAPTISTA, S. T. C. Cultura política brasileira, práticas pentecostais e neopentecostais: a presença da Assembleia de Deus e da Igreja Universal do Reino de Deus no Congresso Nacional (1999-2006). São Bernardo do Campo: 2007. Tese (Doutorado em Ciências da Religião). Universidade Metodista de São Paulo, 2007.

CAMPOS, L. S. Teatro, templo e mercado. $2^{\circ}$ ed. Petrópolis, São Paulo, São Bernardo do Campo: Editora Vozes, Simpósio Editora, Editora Umesp, 1999.

. De "políticos evangélicos" a "políticos de Cristo": la trayectoria de las acciones y mentalidad politica de los evangélicos brasileños em el paso del siglo XX ao siglo XXI. Porto Alegre: Ciencias Sociales y Religión/ Ciências Sociais e Religião. Ano 7, n. 7, p. 157-186, 2005

CURITIBA, CÂMARA MUNICIPAL. Marcha para Jesus passa para o calendário de eventos. 2005. Disponível em http://www.cmc.pr.gov.br/ass_det. php?not=4667\#\& panel1-1 Acesso em 26/12/2017.

. Comissão de Legislação, Justiça

e Redação. Parecer n 541/2009. 2009. Disponível em http://www.cmc. pr.gov.br/wspl/sistema/ParecerVerForm.do? select_action $=$ \&ordena $=\mathrm{C} \% 20$ Legisla\%C3\%A7\%C3\%A3o\%2000541\%202009\&popup=s\&chamado_por_ link\&par_id=2055 Acesso em 26/12/2017. 
Audiência debate combate à legalização da maconha. 2011. Disponível em http://www.cmc.pr.gov.br/ass_det. php?not=17165 Acesso em 26/12/2017.

. Evento antidrogas reúne cinco mil

jovens em Curitiba. 2012. Disponível em http://www.cmc.pr.gov.br/ass_det. php?not=18596\#\&panel1-1 Acesso em 24/02/2016.

Nota taquigráfica da sessão ordinária

de 22/06/2015. 2015. Disponível em http://www.cmc.pr.gov.br/wspl/sistema/ ProposicaoConsultaForm.do?resetfull_action= Acesso em 27/12/2017.

Bancada Evangélica tem 11 vereadores.

2013. Disponível em http://www.cmc.pr.gov.br/ass det.php?not=20081 acesso em 05/02/2016.

.Valdemir Soares renuncia, mas nega

ter votado por vereadora. 2016. Disponível em http://www.cmc.pr.gov.br/ ass det.php?not=26236\#\&panel1-1 Acesso em 06/04/2016

FRESTON, P. Protestantes e política no Brasil: da Constituinte ao Impeachment. 1993. Tese (Doutorado em Ciências Sociais). Universidade Estadual de Campinas, Campinas, 1993.

GALINDO, R. W. Evangélicos dominam principais postos na Câmara de Curitiba. Gazeta do Povo. 2015. Disponível em http://www.gazetadopovo.com.br/ blogs/caixa-zero/evangelicos-dominam-principais-postos-na-camara-de-curitiba/ acesso em 17/03/2015.

MAIA, E. L. C. A Política Evangélica: análise do comportamento da Frente Parlamentar Evangélica na Câmara Federal (2007-2010). 2012. Tese (Doutorado em Sociologia Política). Universidade Federal de Santa Catarina, Florianópolis, 2012.

ORO, A. P. A política da Igreja Universal e seus reflexos nos campos religioso e político brasileiros. Revista Brasileira de Ciências Sociais. Vol. 18, $\mathrm{n}^{\circ} .53$, outubro, 2003.

PROENÇA, W. L. Sindicato de mágicos: uma história cultural da Igreja Universal do Reino de Deus. São Paulo: Editora Unesp, 2011.

REHBEIN, M. P. Curitiba - $\mathbf{5 0}$ anos de eleições municipais - as forças políticas que nas democracias e no governo militar disputam o poder. 2008. Dissertação (Mestrado em Sociologia). Universidade Federal do Paraná, Curitiba, 2008.

SOARES, V. Projeto de Lei Ordinária: Estabelece a obrigatoriedade dos estabelecimentos de ensino localizados no Município, afixarem em local visível, com destaque, os malefícios do fumo, bebidas alcoólicas e drogas. 2001. Disponível em http://www.cmc.pr.gov.br/wspl/sistema/ProposicaoConsultaResultadoForm.do Acesso em 27/12/2017. 
. Requerimento 044.08118.2001 à Prefeitura de Curitiba. 2001b. Disponível em http://www.cmc.pr.gov.br/wspl/sistema/ProposicaoConsultaResultadoForm.do Acesso em 27/12/2017.

. Projeto de Lei Complementar: Dispõe sobre a isenção de pagamento do Imposto sobre a Propriedade Territorial e Urbana - IPTU, às entidades que menciona e dá outras providências. 2002. Disponível em http://www.cmc.pr.gov.br/wspl/sistema/ProposicaoConsultaResultadoForm.do Acesso em 26/12/2017.

. Projeto de Lei Ordinária: Dispõe sobre a instituição da Marcha para Jesus. 2002b. Disponível em http://www.cmc.pr.gov.br/wspl/sistema/ ProposicaoConsultaResultadoForm.do Acesso em 26/12/2017.

. Voto em separado: Comissão de Legislação Justiça e Redação. 2015. Disponível em http://www.cmc.pr.gov.br/wspl/sistema/ProposicaoConsultaResultadoForm.do Acesso em 27/12/2017.

SOUZA, Políticas Públicas: uma revisão da literatura. Sociologias, Porto Alegre, ano 8, nº 16, jul/dez 2006, p. 20-45.

SOUZA. E. S. Cristãos em confronto: discórdias entre intelectuais religiosos num Estado não confessional (Brasil, 1890-1960). 2012. Tese (Doutorado em História). Universidade Federal do Paraná, Curitiba 2012.

STEPHANES JR., R. Emenda Aditiva à Proposição n 05.00183.2002, do Projeto de Lei que "Dispõe sobre a instituição da Marcha para Jesus". 2004. Disponível em http://www.cmc.pr.gov.br/wspl/sistema/ProposicaoDetalhesForm.do?select_action $=\&$ popup $=$ s\&chamado_por_link\&pro_ $\mathrm{id}=41828 \&$ PESQUISA Acesso em 26/12/2017. 